\title{
The Effect of Motivational Book Reading on Student's Attitudes Change
}

\author{
Kihwan Kim \\ Kean University \\ Mitchell Lanzl \\ Kean University
}

\begin{abstract}
Student's attitudes influence academic performances. In particular, self-efficacy, locus of control, and selfesteem had a positive impact on GPA, retention rate, satisfaction with college life. Despite the importance of students' attitudes in academic performance, there have been few studies on how positive attitudes can be developed. We examined the impact of motivational book reading on the development of self-efficacy, self-esteem, and locus of control. 96 business students participated in the experiment. The analysis revealed that motivational book reading significantly increased self-efficacy and locus of control. Additional exploratory analysis revealed that emotional intelligence positively influenced the change of self-esteem and locus of control. We discussed practical implications and future research issues.
\end{abstract}

Keywords: vicarious learning, motivational book reading, self-efficacy, locus of control, emotional intelligence

\section{INTRODUCTION}

Judge et al. (2004) argued that core self-evaluation is a higher-order concept representing the fundamental evaluations that people make about themselves and their functioning in their environment. Individuals with positive core self-evaluation appraise themselves in a consistently positive manner across situations. Among various workplace attitudes, core self-evaluation has been highlighted as critical one that has impacts on a variety of job performances such as job satisfaction and job performance (e.g., Judge \& Bono, 2001), career adaptability and organizational citizenship behavior (OCB) (Xu \& Yu, 2019), turnover (Ahn, 2015) and leader performance (Ahn et al., 2018).

Similar to the cases in the workplace, students' attitude matters to their academic performances, including GPA, satisfaction, class drop, retention rate, job placement rate. A stream of studies found that students' self-efficacy, self-esteem, and locus of control have a positive impact on the students' retention rate (Gifford et al., 2006). Besides retention rate, students' positive attitudes such as self-efficacy and locus of control are one of the most prominent antecedents of student's successful performances such as the number of accumulated credits, GPA, satisfaction with college life (Anderson et al., 2005; Wang, 2005:Zajacova et al., 2005). Although the scholars found that students' self-efficacy, self-esteem, and locus of control play a critical role in determining academic performances, there are few studies on the program to develop students' self-efficacy, self-esteem, and locus of control. 
Based on social learning theory (Bandura, 1977), researchers have advanced the concept of "vicarious learning" to capture these learning and performance benefits, defining the term as the process by which "an observer learns from the behavior and consequences experienced by a model rather than from outcomes stemming from his or her performance attempts (Gioia \& Manz, 1985). Vicarious learning refers to the individual learning that occurs through being exposed to and making meaning from another's experience (Myers, 2018). Learning from the experience of others has long been recognized as critical for individual and organizational success (Bresman, 2013). Grounded on the vicarious learning theory, we developed a program that aims to develop students' self-efficacy, locus of control, and self-esteem by reading a book that delivers an inspirational message of the importance of positive attitudes.

Thus, through the research, we ask the following research questions:

- Does the motivational book reading have a positive impact on students' self-efficacy, locus of control, and self-esteem?

- How does a student's personality affect the magnitude of attitude changes?

- How much does emotional intelligence influence the magnitude of attitude changes?

By answering these questions, the current study contributes to the extant research on students' attitudes and emotional intelligence in several ways. Firstly, this research empirically tests the effects of motivational book reading on the improvement of students' self-efficacy, locus of control, and self-esteem. There have been few studies on the program for improving self-efficacy, locus of control, and self-esteem. Secondly, this study collected longitudinal data to examine the changes in students' attitudes and the effect of emotional intelligence. Thirdly, this study provides valuable implications for administrators and professors regarding curriculum development, student development, and retention. The following sections will discuss theory development, research methodology, findings, and conclusions.

\section{HYPOTHESES DEVELOPMENT}

\section{Self-Efficacy}

Self-efficacy refers to a belief a person has about their ability and likelihood of completing a task successfully. Self-efficacy plays a crucial role in human achievement, attitude, and performance on both specific tasks and overall performance levels (Bandura, 1997). People who view their actions have highly efficaciously put forth more effort into completing tasks. When self-efficacy is diminished, individuals will prematurely end the task before completion because they are not confident they can complete the task (Stajkovic \& Luthans, 1998).

Self-efficacy has an impact on employee's performance. Self-efficacy has been studied in conjunction with many workplace issues, including group effectiveness (Prussia \& Kinicki. 1996), sales (Carter et al., 2018) and service performance (Yoon \& Yoon, 2019), creativity and productivity (Tierney \& Fanner, 2002; Walumba et al., 2018) and performance and idea generation (Wood et al., 1990). Also, self-efficacy has been related to adaptability to advanced technology (Gist et al., 1989), coping with career-related event (Stumper et al., 1987), computer-related tasks (Stone \& Henry, 2003), career choice (Lent et al., 1987), and organizational change (Judge et al., 2004). These studies largely indicate that self-efficacy is positively related to more desirable workplace outcomes, including higher group and managerial effectiveness, skill acquisition, and higher adaptability. Recent study reveals that the existence of the revere relationship between self-efficacy and task performance. Howard (2019) found that task performance is shown to influence self-efficacy even without increases in the skills required to achieve success.

In a similar vein, self-efficacy has shown positive effects on students' academic performances. Bandura (1993) argued that self-efficacy beliefs would affect college outcomes by promoting motivation and persistence for students to keep working on the challenging academic tasks. Romas Salazar and Hayward (2018) revealed that academic self-efficacy is related to student motivation and served as a predictor of the expected grade. Torres and Solberg (2001) found that academic self-efficacy was positively related to the number of hours students spent studying. In a study that explored the relationship among self-efficacy, stress and academic success in college, Zajacova et al. (2005) argued that self-efficacy is the strong, significant predictor of academic performance in all models, even considering the performance in high 
school and demographic factors. When compared to other metrics in a college student's life, self-efficacy is the most prominent factor.

\section{Locus of Control}

Locus of control refers to where an individual designates control over events that occur to them (Rotter, 1966). Someone with an external locus attributes outside factors for life events, whereas someone with internal locus credits themselves for outcomes. Those who have an internal locus tend to be more selfmotivated and independent. (Spector, 1982).

Locus of control has been found to influence education, employees' performance, and labor market outcomes. Previous studies have shown that internal locus of control increases the probability of graduating from high school and the probability of attending college (Baron \& Cobb-Clark 2010; Coleman \& DeLeire, 2003). Turnipseed (2018) revealed that locus of control moderated the relationship between an employee's emotional intelligence and organizational citizenship behavior. In a study with the sample of African engineers, Modies and Rambe (2017) found that there is a positive relationship between self-esteem and job performance.

Studies have also demonstrated that internal locus of control has positive effects on the level and growth of earnings and occupational advancement (Groves, 2005; Heckman et al., 2006). Also, Duncan and Dunifon (1998) found that the perception of self-efficacy predicted future wages and labor market success 15 - 20 years later, which supports the notion that motivational factors and perception of control have persistent influences on labor market outcomes. Taken together, past studies revealed that locus of control has both direct and indirect effects on wages and labor market outcomes.

In the academic context, locus of control has shown similar effects on students' performances. Numerous studies demonstrated that students with an external locus of control are considered to be at higher risk of non-persistence (Anderson et al., 2005; Gifford et al., 2006; Morris et al., 2005). Nowicki et al. (2004) reported that external locus of control was related to lower academic achievement and higher rates of dropping out. While it is reasonable to state that students who have external locus of control trait may be more at risk for dropping out of college and showing poor academic performances (Bursik \& Martin, 2006; Gifford et al., 2006), it might also be reasonable to suggest that students with internal locus of control are more likely to remain enrolled in an institution of higher education.

\section{Self-Esteem}

Self-esteem is defined as a favorable or unfavorable attitude toward the self (Rosenberg, 1965). Blascovich and Tomaka (1991) discussed that self-esteem is the evaluative component of the self-concept that covers cognitive and behavioral aspects as well as affective ones. Coopersmith (1981) described selfesteem as a process of integration, where the individual becomes a member of the group and internalizes ideas and attitudes as a mirror image, via key figures and by observing actions and attitudes.

Past studies have witnessed that self-esteem is a significant predictor of individual and group performance in the workplace. High self-esteem is linked to task liking (Tang \& Sarsfield-Baldwin, 1991) and hotel employee's performance (Akgunduz, 2015). In particular, low self-esteem is associated with various negative behaviors and performance. Past studies have found that low self-esteem has been associated with anxiety (Mischel et al., 1976), task avoidance and the arousalof intense emotion (Brockner $\&$ Wallnau, 1981), resistance to the communication of negative feedback (Brockner et al., 1977).

In the academic context, self-esteem also plays a crucial role in determining students' academic performances. Grant-Vallone et al. (2003) found students who reported higher levels of self-esteem and more peer support had a better academic and social adjustment. Research has demonstrated that students with certain personality characteristics, such as high levels of self-esteem, are better able to adjust both socially and academically within college environments. In a recent longitudinal study, Chemers and his colleagues (2001) found that academic self-efficacy and optimism were important for first-year student's adjustment and performance. Similarly, Napoli and Wortman (1998), from a longitudinal study of 1,011 college freshman, found that students who had higher levels of self-esteem were associated with high levels 
of college adjustment. From the study of high school students, Alam (2013) revealed that there is a positive relationship between self-esteem and academic performance.

\section{Vicarious Learning}

Vicarious learning refers to the individual learning that occurs through being exposed to and making meaning from another's experience (Myers, 2018). Learning from the experience of others has long been recognized as critical for individual and organizational success (Bresman, 2013). Grounded on Social learning theory (Bandura, 1977), researchers have advanced the concept of "vicarious learning" to capture these learning and performance benefits, defining the term as the process by which "an observer learns from the behavior and consequences experienced by a role model rather than from outcomes stemming from his or her own performance attempts" (Gioia \& Manz, 1985). Vicarious learning occurs when learners decide, after viewing the performances of others, what types of actions will be effective or non-effective for their own enactment of a task (McCown et al., 1996). Sumpter et al. (2017) found that employees got empowered by observing their supervisor, who demonstrates autonomy and expediency. Afota et al. (2019) proposed that subordinates mimic the supervisor's long working hours through vicarious learning. According to social cognitive theory (Bandura, 1997; Schunk, 2000), vicarious experiences can accelerate learning over what would be possible if we had to perform every behavior ourselves to learn. This is especially true when trying to learn complex skills such as riding a bike, swinging a golf club, or using computers in the classroom. By observing experts, teachers, and other models, learners may get a head start toward their own mastery of difficult tasks. Vicarious experiences have been used to increase students' self-efficacy, or confidence, for performing tasks similar to those performed by the observed models (Bandura, 1986; Ertmer et al., 2003; Gist et al., 1989).

Vicarious learning theory states the people learn through the observations of others. Since developing positive altitudes is critical to the success of students, we decided to test if observing positive behavior through reading a book will impact a student's core-self-evaluation.

This study picked one book that includes the message of the importance of self-efficacy, locus of control, and self-esteem. "The Promise of Pencil: How Can an Ordinary Person Create an Extraordinary Change?" describes the journey of a young social entrepreneur who built a non-profit organization which has built schools for kids in underdeveloped countries. Through the story, the authors exemplify how he overcomes the challenges and not to give up to achieve his dream. In particular, the book is composed of thirty chapters, and even the title of each chapter inspires students. The titles of chapters reflect these messages. "Get out of your comfort zone," "Why to be normal," "If your dream doesn't scare you, it is not big enough."

The book also has received many good comments from readers:

- How something changed lives forever. This book changes your perspective on life.

- Read this book but only if you are willing to be inspired and make some changes

- For anyone with a big dream to transform the world, this book will show you how to get it done.

- A remarkably inspiring story that shares the essential lessons to creating a life of meaning, passion, and purpose.

Grounded on vicarious learning theory, this study proposes that students who read a motivational book that delivers the message of the importance of self-efficacy, locus of control, and self-esteem will be motivated to develop those attitudes for themselves. Based on the discussion in this section, this study develops the following hypotheses:

Hypothesis 1a: Motivational book reading will positively influence the reader's self-efficacy.

Hypothesis 1b: Motivational book reading will positively influence the reader's locus of control.

Hypothesis 1c: Motivational book reading will positively influence the reader's self-esteem. 


\section{Emotional Intelligence, and the Change of Self-Efficacy and Locus of Control}

In the previous section, this study developed the hypothesis that motivational book reading will have an impact on the change in students' attitudes. Furthermore, this study seeks to explore individual characteristics that might have an impact on the magnitude of attitude changes. Plentiful studies have demonstrated that emotional intelligence is associated with self-efficacy (Black et al., 2019; Gundlach et al., 2003), locus of control (Mohapatra \& Gupta, 2010; Turnipseed, 2018), and self-esteem (Cheung et al., 2015; Dust et al., 2018). However, the findings on the relationship between emotional intelligence and these attitudes cannot make us conclude that emotional intelligence has an impact on these attitude changes. Also, few studies have been done to examine the relationship between emotional intelligence and the changes in attitudes. Thus, this study runs an additional analysis to explore whether emotional intelligence has an impact on the changes of attitudes as a result of motivational book reading.

Based on the discussion above, we suggested the following hypotheses for exploratory analysis:

Hypothesis 2a: Emotional intelligence will have a positive association with the change of Self-efficacy as a result of reading a motivational book.

Hypothesis 2b: Emotional Intelligence will have a positive association with the change of Locus of Control as a result of reading a motivational book.

Hypothesis 2c: Emotional Intelligence will have a positive association with the change in self-esteem as a result of reading a motivational book.

\section{RESEARCH METHODOLOGY}

\section{Participants}

Participants are junior and senior business major students in the small-sized university in the Midwest of the United States. Participants are asked to read the book, "The Promise of the Pencil" as an assignment of their course work and to write essays to reflect their learning from the book. The assignment takes up $10 \%$ of their total grade in the course. Also, to motivate students to participate in the research, $3 \%$ of the total grade is provided as an incentive in participating in the research. A total of 96 students participated in the research. Out of the participants, $52 \%$ are female and $48 \%$ are male; $13 \%$ are white, 25 are black, $32 \%$ are Hispanic, $12 \%$ are Asian, and 3\% are combined more than two. Average age of the participants is 24.1 years old.

\section{Experiment}

During the experiment, the participants took two surveys before (time 1) and after (time 2) reading the book. The first survey measured students' personality type, emotional intelligence, self-efficacy, and locus of control, self-esteem, and demographic information while the second survey measured only self-efficacy, locus of control, and self-esteem. The researchers provided the participants about one and half months for completing reading the book. During this period, the participants submitted four short essays to reflect their learning from the book.

For this research, we selected the book, "The Promise of Pencil". The book illustrates the story of young social entrepreneur, Adan Brown, who established a non-profit organization.

The book provides students with the opportunity to learn about how to start and manage the operations and the required traits for successful entrepreneurship.

\section{Measures}

Self-Efficacy

The participant's general self-efficacy was measured using the scale developed by Schwarzer and Born (1997, $\alpha=91$; the current study $\alpha=.86$ ). The scale has ten items and assesses the belief in one's ability to succeed in specific situations or accomplish a task. Some example items are: "I am confident that I could 
deal efficiently with unexpected events," "I can solve most problems if I invest the necessary effort," and "I can usually handle whatever comes my way." The items are assessed on a five-point scale, with " 1 " representing "strongly disagree" and " 5 " representing "strongly agree."

\section{Self-Esteem}

Self-esteem was measured by the Rosenberg Self-Esteem Scale (Rosenberg, 1965). These items were affective and evaluative reactions to self. Some example items include, "I certainly feel useless at times," "I am able to do things as well as most other people," and "On the whole, I am satisfied with myself." Responses were summed to obtain the general self-esteem measure. The items are assessed on a five-point scale, with " 1 " representing "strongly disagree" and " 5 " representing "strongly agree." The Cronbach's alpha for this scale in the current study is .80 .

\section{Locus of Control}

Locus of control was assessed with Rotter's (1966) Internal-External (I-E) Scale. The original I-E scale consists of 23 items arranged in a paired-comparison format. Subjects indicated for each of the 23 items which of two statements matched their beliefs, and their responses were summed. Higher scores represented an external locus of control. The Cronbach's alpha for this scale in the current study is .72.

\section{Emotional Intelligence}

This study measured the participants' perceptions of their own emotional intelligence using the scale developed by Law et al. (2004). The sixteen-item scale assesses four dimensions of emotional intelligence: appraise self-emotion, appraise others' emotion, use emotion, and regulate emotion. Some example items of the scale are "I am sensitive to the feelings and emotions of others," "I can always calm down quickly when I am very angry," and "I am a self-motivated person". The items are assessed on a five-point Likert scale, with " 1 " representing "strongly disagree" and " 5 " representing "strongly agree." The Cronbach's alpha for this scale in the current study is .87 .

\section{Big Five Personality}

The big five personalities of the participants, namely openness, extraversion, conscientiousness, agreeableness, and neuroticism, were measured using the Big Five theory (McCrae \& Costa, 1987). Measures of the personality traits that we used in our study have been frequently cited in the literature of management and psychology. The items are assessed on a five-point Likert scale, with " 1 " representing "strongly disagree" and " 5 " representing "strongly agree." The Cronbach's alpha for this scale in the current study is .84 .

\section{DATA ANALYSIS}

To test the hypotheses, we ran a paired $\mathrm{T}$ test and multiple regression using SPSS Version 25. Hypothesis 1a predicted that motivational book reading would have a positive impact on the change of selfefficacy. A paired-samples t-test was conducted to compare the level of self-efficacy before and after the book reading. There was a significant difference in the scores for self-efficacy before reading book $(\mathrm{M}=3.45$, $\mathrm{SD}=1.13)$ and after reading book $(\mathrm{M}=3.86, \mathrm{SD}=1.24)$ conditions; $\mathrm{t}(\mathrm{df}=94)=13.42, \mathrm{p}<.001$. These results suggest that motivational book reading improved participants' self-efficacy levels. Thus, hypothesis 1a was supported.

Hypothesis $1 \mathrm{~b}$ proposed that motivational book reading will have a positive impact on the change of locus of control. A paired-samples t-test was conducted to compare the change of locus of control before and after the book reading. The analysis indicated a significant change in the scores of locus of control between before reading book $(\mathrm{M}=10.14, \mathrm{SD}=4.04)$ and after reading book $(\mathrm{M}=9.01, \mathrm{SD}=3.88)$ conditions; $\mathrm{t}(\mathrm{df}=94)=-5.81, \mathrm{p}<.001$. These analyses outcomes indicate that motivational book reading improved participants' locus of control. Thus, hypothesis $1 \mathrm{~b}$ was supported. 
Hypothesis 1c predicted that motivational book reading would have a positive impact on the change of self-esteem. A paired-samples t-test was conducted to compare the level of self-esteem before and after the book reading. There was no significant difference in the scores for self-esteem before reading book $(\mathrm{M}=2.45$, $\mathrm{SD}=.79)$ and after reading book $(\mathrm{M}=2.47, \mathrm{SD}=.81)$ conditions; $\mathrm{t}(\mathrm{df}=94)=.94, \mathrm{p}=35$. These results suggest that motivational book reading didn't have an impact on the changes of participant's self-esteem level. Thus, hypothesis $1 \mathrm{c}$ was not supported.

\section{FIGURE 1 \\ ATTITUDE CHANGES AFTER READING BOOK}

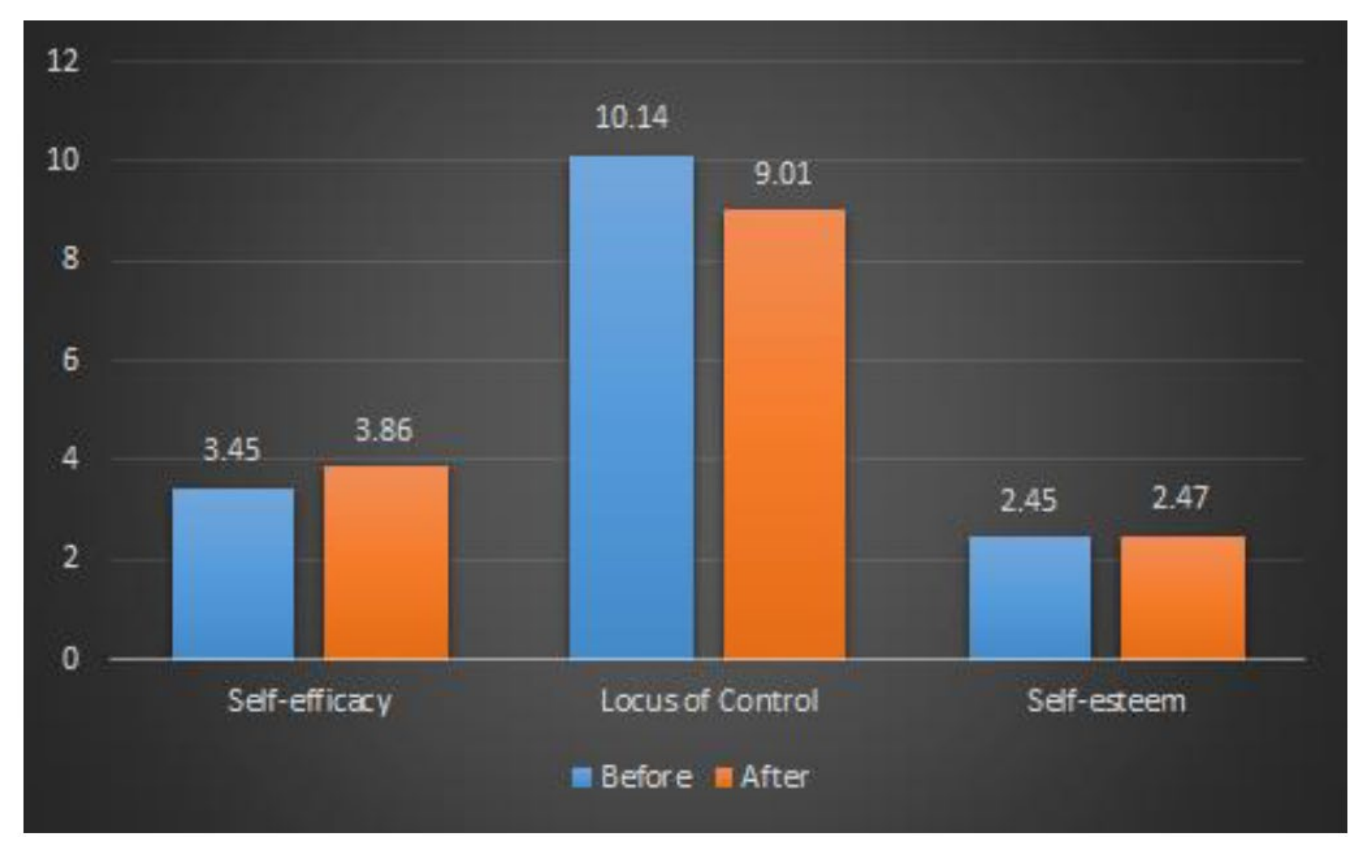

Also, this study hypothesized that emotional intelligence would have a positive impact on the magnitude of attitude changes. We tested the hypotheses using multiple regression. Table 1 presents the regression analysis outcome. For each dependent variable, we entered demographic variables and personality type as control variables in the first step and then entered emotional intelligence at step 2 to see if emotional intelligence explained significant variation in the change of self-efficacy, locus of control, and self-esteem.

Hypothesis 2a predicted that emotional intelligence has a positive association with self-efficacy change. The control model examined the effect of demographic variables and personality on self-efficacy change. The result demonstrated that no demographic variables and personality dimensions significantly predict the self-efficacy change. In the full model, emotional intelligence was not a significant predictor of self-efficacy change, and the addition of emotional intelligence to the control model didn't add any incremental contribution to $R^{2}$ and $F$ value significantly. Hence, hypothesis 2 a was not supported.

Hypothesis $2 \mathrm{~b}$ predicted that emotional intelligence is positively related to locus of control change. At step 1, the control model examined the effect of demographic variables and personality on students' locus of control change. In the control model, the result demonstrated that no demographic variables and personality dimensions significantly predict the locus of control change. In the full model, emotional intelligence $(\beta=.32, \mathrm{p}<.05)$ was a strong, significant predictor of the change of locus of control. Also, the addition of EI produced a significant increase in $R^{2}$ (from $22 \%$ to $30 \%, \mathrm{p}<.05$ ), indicating that EI added significant explanatory power and explained an additional $8 \%$ of the total variance in the change of locus of control. Hence, the hypothesis $2 \mathrm{~b}$ was supported. 
Hypothesis $2 \mathrm{c}$ predicted that emotional intelligence is positively related to the change in self-esteem. At step 1, the control model examined the effect of demographic variables and personality on students' selfesteem change. In the control model, the result demonstrated that no demographic variables and personality dimensions significantly predict the locus of control change. In the full model, emotional intelligence $(\beta$ $=.57, \mathrm{p}<.001$ ) was a strong, significant predictor of self-esteem change. Also, the addition of EI produced a significant increase in $R^{2}$ (from $12 \%$ to $36 \%, \mathrm{p}<.05$ ), indicating that EI added significant explanatory power and explained an additional $24 \%$ of the total variance in the change of self-esteem. Hence, the hypothesis $2 \mathrm{c}$ was supported.

TABLE 1

REGRESSION ANALYSIS OUTCOME

\begin{tabular}{llccccc}
\hline & \multicolumn{2}{c}{$\begin{array}{c}\text { Self-Efficacy } \\
\text { Change }\end{array}$} & \multicolumn{2}{c}{$\begin{array}{c}\text { Cocus of Control } \\
\text { Change }\end{array}$} & \multicolumn{2}{c}{$\begin{array}{c}\text { Self-esteem } \\
\text { Change }\end{array}$} \\
& \multicolumn{1}{c}{$\begin{array}{c}\text { Control } \\
\text { Model }\end{array}$} & $\begin{array}{c}\text { Full } \\
\text { Model }\end{array}$ & $\begin{array}{c}\text { Control } \\
\text { Model }\end{array}$ & $\begin{array}{c}\text { Full } \\
\text { Model }\end{array}$ & $\begin{array}{c}\text { Control } \\
\text { Model }\end{array}$ & $\begin{array}{c}\text { Full } \\
\text { Model }\end{array}$ \\
\hline $\begin{array}{l}\text { Demographic } \\
\text { Variables }\end{array}$ & & & & & & \\
Gender & & & & & & \\
Age & -.20 & -.19 & -.18 & -.12 & .01 & .12 \\
GPA & .09 & .09 & .22 & .22 & -.05 & -.05 \\
Race & -.05 & -.05 & .21 & .20 & -.03 & -.05 \\
Personality & .14 & .13 & .01 & -.08 & .09 & -.06 \\
Extrovertness & & & & & & \\
Agreeableness & .26 & .25 & -.04 & -.07 & -.05 & -.10 \\
Consciousness & .01 & .01 & -.17 & -.23 & .13 & .01 \\
Neuroticism & -.39 & -.39 & .19 & .14 & .03 & -.05 \\
Openness & -.03 & -.03 & .14 & .18 & -.15 & -.09 \\
& .16 & .16 & .25 & .28 & .21 & .28 \\
Emotional Intelligence & & & & & & \\
& & .05 & & $.32 *$ & & $.57 * * *$ \\
R2 & & & & & & \\
Adjusted R2 & .24 & .24 & .22 & .30 & .12 & .36 \\
F Value & .08 & .06 & .05 & .12 & .08 & .21 \\
Incremental R & 1.31 & 1.26 & $2.54 *$ & .61 & $2.29 *$ \\
Incremental F & 1.48 & .00 & & .08 & & .24 \\
\hline
\end{tabular}

\section{FINDINGS}

Grounded on vicarious learning theory, the current study hypothesized that motivational book reading would have a positive influence on the reader's self-esteem, self-efficacy, and locus of control. The analysis outcomes revealed that reading a motivational book had improved the level of participants' locus of control, and self-efficacy significantly. Besides quantitative analyses of data, we did a preliminary qualitative analysis using students' essays. This study asked participants to write an essay about their overall learning from reading the book. From the essays, we caught many comments to imply the change of self-efficacy and locus of control:

- What I have learned from reading this book is that you control your own fate.

- This book not only made me confident in me wanting and knowing I will be successful but also tells me you can start from nothing and still make it. 
- Some things that I have learned from the book that I want to share is that if you believe in yourself and stay focused on the things you want to accomplish, then it can happen.

- I can say I learned a couple of things from the book. One, do more, see more, and become more.

- This book is very motivating. It taught me how much you can achieve by being determined and persistent.

- Ifelt like reading this book has enabled my thought process more and allowed me to believe in myself more than I ever could have.

This study hypothesized that motivational book reading would change the level of self-esteem. However, the result revealed that this hypothesis was not supported. From the qualitative analysis, we got a hint about the failure to support the hypothesis. We found numerous comments that reflected their learning about self-efficacy and locus of control but few comments about self-esteem. After the careful inspection of the messages of the book, we concluded that actually, the book didn't have a strong message regarding self-esteem.

The findings in this study have many implications for administrators and educators. The higher education research has shown that the number of enrolled students increased, but more numbers of students fall out of their college. The improvement of the retention and graduation rate is one of the biggest challenging issues that face the administrators and faculty in the college community (Tate, 2017). Plentiful studies have been done to explore the factors that might have an impact on the retention rate. A stream of studies found that students' self-efficacy and locus of control have a positive impact on the students' retention rate (Gifford et al., 2006). Besides retention rate, students' positive attitudes such as self-efficacy and locus of control are one of the most prominent antecedents of student's successful performances such as the number of accumulated credits, GPA, satisfaction with college life (Anderson et al., 2005; Wang, 2005; Zajacova et al., 2005). Thus, reading motivational book reading will help students foster their positive changes in the short term and the long term, benefit both students and institutions by improving academic performance, satisfaction, and retention rate. This finding provides important practical implications for educators. The university includes motivational book reading as a crucial part of the curriculum. Also, the development of positive attitudes will benefit students in their long term career. Plentiful studies have witnessed that self-efficacy and locus of control have a substantial impact on employees' performance including organizational citizenship behavior (Turnipseed, 2018), turnover (Ahn, 2015), team performance (Black et al., 2019), and leadership effectiveness (Ahn et al., 2018).

Another interesting finding is that EI had a positive impact on the magnitude of attitude change, meaning that highly emotionally intelligent people showed more positive changes in self-efficacy and locus of control after reading motivational books. Our study sheds new light on the research on EI and attitude changes. Attitude consists of three components: cognitive aspect, affective aspect, and behavioral aspect (Kinicki \& Fugate, 2018). Thus, an emotional stimulus such as inspirational book reading is likely to lead to a person's attitude changes. Mayer et al., (2004) claimed that emotional intelligence helps people to appraise the emotional information and utilize them more effectively. Thus, when there is emotional stimulus, highly emotionally intelligent people are more likely to catch and internalize emotional learning. Past studies have witnessed that emotional learning has a deeper impact on cognitive learning in certain contexts (Wang, 2005). Our finding implies that emotionally intelligent people will have learning performance from emotional learning.

\section{CONCLUSIONS}

This study sheds new light on the literature on core self-evaluation, in particular in the academic setting, by finding the impact of motivational book reading on students' attitude changes. Also, through the qualitative analysis, this study enhanced the findings from the quantitative analysis. In particular, this study contributes to the extant research on students' attitudes and emotional intelligence in several ways. First, this research empirically tests the effects of motivational book reading on the improvement of students' selfefficacy and locus of control. There have been few studies on the program for improving self-efficacy, 
locus of control, and self-esteem. Secondly, this study collected longitudinal data to examine the changes in students' attitudes and the effect of emotional intelligence. Thirdly, this study provides valuable implications for administrators and professors regarding curriculum development, student development, and retention.

\section{Limitations}

This study should address the weaknesses embedded in the current research. Firstly, the participants were junior and senior business major students in the east coast area in the U.S. Thus, there is a limitation in generalizing the result to other population groups. It needs to be careful in applying the outcome of the study.

Secondly, this study attempted to test the effect of motivational book reading on the reader's attitude changes employing a quasi-experiment design. This research design has a limitation in controlling unexpected impact from the outside of the experiment. For example, during the experiment period, some participants might have read another inspirational book or had personal experience to influence their attitudes.

Thirdly, this study hypothesized that motivational book reading would affect the reader's self-esteem. However, the result didn't support the hypothesis. As we mentioned in the finding section, this outcome might be the result since the book didn't deliver a strong message of self-esteem.

Lastly, this study collected the data from the only participants' survey. Thus, this study is likely to have a weakness of common method bias.

\section{Future Research Issues}

This study collected both quantitative and qualitative data. Although survey data provided valuable information about the relationship between book reading and attitudes change, often qualitative data source can provide a deeper level of information that quantitative data cannot do. In the current study, we did only a primitive qualitative analysis by picking comments that imply attitude changes manually. Future research needs to carry more systematic qualitative analysis using an advanced software for content analysis (e.g., NVivo). The rigorous qualitative analysis might be able to deliver new findings or reinforce the findings from the quantitative analysis.

In the current research, to enhance the learning effect from reading the book, the researchers asked participants to write essays to reflect their learning. Besides writing an essay, future research needs to consider more techniques such as group discussion, role-playing, etc. to increase the learning effects and compare the effects of each technique on the magnitude of attitude changes.

The current study revealed that reading motivational stories can have an impact on the changes in students' attitudes. Past studies found that students' self-efficacy, self-esteem, and locus of control were related to retention rate (Gifford et al., 2006), academic performance, and satisfaction with college life (Anderson et al., 2005; Wang, 2005: Zajacova et al., 2005). Future study needs to develop a long-term project that can investigate how motivational book reading leads to the increases in retention rate, academic performance, and satisfaction (long-term outcomes) via the improved attitudes (short-term outcome).

\section{REFERENCES}

Afota, M., Ollier-Malaterre, A., \& Vandenberghe, C. (2019). How supervisors set the tone for long hours: Vicarious learning, subordinates' self-motives and connotation of working hours. Human Resource Management Review, 29, 1-15.

Ahn, J., Lee, S., \& Yum, S. (2018). Leaders' core self-evaluation, ethical leadership, and employees' job performance: The moderating role of employees' exchange ideology. Journal of Business Ethics, $148,457-470$.

Ahn, T. (2015). Locus of control and job turnover. Economic Inquiry, 53(2), 1350-1365.

Akgunduz, Y. (2015). The influence of self-esteem and role stress on job performance in hotel businesses. International Journal of Contemporary Hospitality Management, 27(6), 1082-1099. 
Alam, M.M. (2013). A Study of Test Anxiety, Self-Esteem and Academic Performance Among Adolescents. IUP Journal of Organizational Behavior, 12(4), 33-43.

Anderson, A., Hattie, J., \& Hamilton, R.J. (2005). Locus of control, self-efficacy, and motivation in different schools: Is moderation the key to success? Educational Psychology, 25(5), 517-535.

Bandura, A. (1977). Self-efficacy: Toward a unifying theory of behavioral change. Psychological Review, 84(2), 191-215.

Bandura, A. (1986). Social foundations of thought and action: A social cognitive theory. Prentice-Hall Inc.

Bandura, A. (1993). Perceived self-efficacy in cognitive development and functioning. Educational Psychologist, 28(2), 117-149.

Bandura, A. (1997). Self-efficacy: The exercise of control. MacMillan.

Baron, J.D., \& Cobb-Clark, D.A. (2010). Are young people's educational outcomes linked to their sense of control? IZA Discussion Paper. Institute for the Study of Labor (IZA).

Black, J., Kim, K., Rhee, S., Wang, K., \& Sakchutchawan, S. (2019). Self-efficacy and emotional intelligence. Team Performance Management, 25(1/2), 100-119.

Blascovich, J., \& Tomaka, J. (1991). Measures of self-esteem. In J.P. Robinson, P.R. Shaver, \& L.S. Wrightsman (Eds.), Measures of Personality and Social Psychological Attitudes (Volume I). Academic Press.

Bresman, H. (2013). Changing routines: A process model of vicarious group learning in pharmaceutical R\&D. Academy of Management Journal, 56(1), 35-61.

Brockner, J., \& Wallnau, L.B. (1981). Self-esteem, anxiety, and the avoidance of self-focused attention. Journal of Research in Personality, 15, 277-291.

Brockner, J., Derr, W.R., \& Laing, W.N. (1977). Self-esteem and reactions to negative feedback: Towards greater generalizability. Journal of Research on Personality, 13, 161-174.

Bursik, K., \& Martin, T.A. (2006). Ego development and adolescent academic achievement. Journal of Research on Adolescence, 16(1), 1-18.

Carter, W.R., Nesbit, P.L., Badham, R.J., Parker, S.K., \& Sung, L.K. (2018). The effects of employee engagement and self-efficacy on job performance: A longitudinal field study. International Journal of Human Resource Management, 29(17), 2483-2502.

Chemers, M.M., Hu, L., \& Garcia, B.F. (2001). Academic self-efficacy and first year college student performance and adjustment. Journal of Educational Psychology, 93, 55-64.

Cheung, C.K., Cheung, H.Y., \& Hue, M.T. (2015). Emotional intelligence as a basis for self-esteem in young adults. Journal of Psychology, 149(1), 63-84.

Coleman, M., \& DeLeire, T. (2003). An economic model of locus of control and the human capital investment decision. Journal of Human Resources, 38(3), 701-21.

Coopersmith, S.A. (1981). The antecedents of self-esteem. San Francisco Freeman.

Duncan, G.J., \& Dunifon, R. (1998). Soft-skills and long-run labor market success. In S. Polachek (Ed.), Research in Labor Economics. JAI Press.

Dust, S.B., Rode, J.C., Arthaud, D.M.L., Howes, S.S., \& Ramaswami, A. (2018). Managing the selfesteem, employment gaps, and employment quality process: The role of facilitation-and understanding-based emotional intelligence. Journal of Organizational Behavior, 39(5), 680-693.

Ertmer, PA., Conklin, D., Lewandoski, J., Osika, E., Selo, M., Wignall, E. (2003). Increasing preservice teachers' capacity for technology integration through the use of electronic models. Teacher Education Quarterly, 30(1), 95-112.

Gifford, D.D., Briceno-Perriott, J., \& Mianzo, F. (2006). Locus of control: Academic achievement and retention in a sample of first-year university students. Journal of College Admission, 191, 19-25.

Gioia, D.A., \& Manz, C.C. (1985). Linking cognition and behavior: A script processing interpretation of vicarious learning. Academy of Management Review, 10(3), 527-539.

Gist, M.E., Schwoerer, C., \& Rose, B. (1989). Effects or alternative training methods on self-efficacy and performance in computer software training. Journal of Applied Psychology, 74, 884-891. 
Grant-Vallone, E., Reid, K., Umali, C., \& Pohlert, E. (2003). An analysis of the effects of self-esteem, social support, and participation in student support services on students' adjustment and commitment to college. Journal of College Student Retention, 5(3), 255-274.

Groves, M.O. (2005). How important is your personality? Labor market returns to personality for women in the US and UK. Journal of Economic Psychology, 26(6), 827-41.

Gundlach, M.J., Martinko, M.J., \& Douglas, S.C. (2003). Emotional Intelligence, Causal Reasoning, and the Self-Efficacy Development Process. International Journal of Organizational Analysis, 11(3), 229-246.

Heckman, J., Stixrud, J., \& Urzua, S. (2006). The effects of cognitive and non-cognitive abilities on labor market outcomes and social behavior. Journal of Labor Economics, 24(3), 411-482.

Howard, M.C. (2019). Task performance influences general self-efficacy, even without increases in the skills required to achieve success. Journal of Social Psychology, 159(5), 642-647.

Judge, T.A., \& Bono, J.E. (2001). Relationship of core self-evaluations traits-Self-esteem, generalized self efficacy, locus of control, and emotional stability - with job satisfaction and job performance: A meta-analysis. Journal of Applied Psychology, 86(1), 80-92.

Judge, T.A., van Vianen, A.E.M., \& De Peter, I.E. (2004). Emotional stability, core self-evaluation, and job outcomes: A review of Evidence and an agenda for future research. Human Performance, 17(3), 325-346.

Kinicki, A., \& Fugate, M. (2018). Organizational behavior: A practical problem-solving approach. McGraw Hill.

Law, K., Wong, C., \& Song, J. (2004). The construct and criterion validity of emotional intelligence and its potential utility for management studies. Journal of Applied Psychology, 89(3), 483-496.

Lent, R.W., Brown, S.D., \& Larkin, K.C. (1987). Comparison of three theoretically derived variables in predicting career and academic behavior: Self-efficacy, interest congruence, and consequence thinking. Journal of Counseling Psychology, 34(3), 293-298.

Mayer, J.D., Salovey, P., \& Caruso, D.R. (2004). Emotional intelligence: Theory, findings, and implications. Psychological Inquiry, 15, 197-215.

McCown R., Driscoll, M., \& Roop, P.G. (1996). Educational psychology: A learning centered approach to classroom practice. Allyn \& Bacon.

McCrae, R.R., \& Costa, P.T. (1987). Validation of the five-factor model of personality across instruments and observers. Journal of Personality and Social Psychology, 52(1), 81-90.

Mischel, W., Ebbesen, E., \& Zeiss, A.R. (1976). Determinants of selective memory about the self. Journal of Consulting and Clinical Psychology, 44, 92-103.

Modise, D., \& Rambe, P. (2017). Internal and external locus of control of engineering workforce in a power distribution utility: Implications for job performance. African Journal of Business \& Economic Research, 12(2/3), 113-147.

Mohapatra, M., \& Gupta, A. (2010). Relationship of Emotional Intelligence with Work Values \& Internal Locus of Control: A Study of Managers in a Public Sector Organization. Vilakshan: The XIMB Journal of Management, 7(2), 1-20.

Morris, L.V., Wu, S., \& Finnegan, C.L. (2005). Predicting retention in online general education courses. American Journal of Distance Education, 19(1), 23-36.

Myers, C.G. (2018). Coactive vicarious learning: Toward a relational theory of vicarious learning in organizations. Academy of Management Review, 43(4), 610-634.

Napoli, A.R., \& Wortman, P.M. (1998). Psychosocial factors related to retention and early departure of two year community college students. Research in Higher Education, 39(4), 419-455.

Nowicki, S., Duke, M.P., Sisney, S., Stricker, B., \& Tyler, M.A. (2004). Reducing the drop-out rate of atrisk high school students: The effective learning program (ELP). Genetic, Social, and General Psychology Monographs, 130(3), 225-39.

Prussia, G.E., \& Kinicki, A.J. (1996). A motivational investigation of group effectiveness using social cognitive theory. Journal of Applied Psychology, 81, 187-198. 
Ramos Salazar, L., \& Hayward, S.L. (2018). An Examination of college students' problem-solving self Efficacy, academic self-efficacy, motivation, test performance, and expected grade in introductorylevel economics courses. Decision Sciences Journal of Innovative Education, 16(3), 217-240.

Rosenberg, M. (1965). Society and the adolescents' self-image. Princeton University Press.

Rotter, J.B. (1966). Generalized expectancies for internal versus external control of reinforcement. Psychological Monographs: General and Applied, 80(1), 1-28.

Schunk, D.H. (2000). Learning theories: An educational perspective. Prentice-Hall.

Schwarzer, R., \& Born, A. (1997). Optimistic self-beliefs: Assessment of general perceived self-efficacy in thirteen cultures. World Psychology, 3(1), 177-190.

Spector, P.E. (1982). Behavior in organizations as a function of employee's locus of control. Psychological Bulletin, 91(3), 482-497.

Stajkovic, W.S., \& Luthans, F. (1998). Self-efficacy and work-related performance: A meta-analysis. Psychological Bulletin, 124(2), 240-261.

Stone, R.W., \& Henry, J.W. (2003). The roles of computer self-efficacy and outcome expectancy in influencing the computer end-user' commitment. Journal of End User Computing, 15, 38-53.

Stumper, S.A., Brief, A.P., \& Hartman, K. (1987). Self-efficacy expectations and coping with careerrelated events. Journal of Vocational Behavior, 31, 91-108.

Sumpter, D.M., Gibson, C.B., \& Porath, C. (2017). Act expediently, with autonomy: Vicarious learning, empowered behaviors, and performance. Journal of Business Psychology, 32, 131-145.

Tang, T.L., \& Sarsfield-Baldwin, L. (1991). The effects of self-esteem, task label, and performance feedback on task liking and intrinsic motivation. Journal of Social Psychology, 131(4), 567572.

Tate, E. (2017, April 26). Graduation rate and race. Inside Higher Ed. Retrieved from https://www.insidehighered.com

Tierney, P., \& Farmer, S.M. (2002). Creative self-efficacy: Its potential antecedents and relationship to creative performance. Academy of Management Journal, 45, 1137-1148.

Torres, J.B., \& Solberg, V.S. (2001). Role of self-efficacy, stress, social integration and family support in Latino college student persistence and health. Journal of Vocational Behavior, 59(1), 53-63.

Turnipseed, D.L. (2018). Emotional intelligence and OCB: The moderating role of work locus of control. Journal of Social Psychology, 158(3), 322-336.

Walumbwa, F.O., Christensen-Salem, A., Ichieh, H., \& Misati, E. (2018). Creative self-efficacy and creative performance: Understanding the underlying mechanisms. Academy of Management Annual Meeting Proceedings, 2018(1), 1-6.

Wang, D. (2005). Student learning and locus of control in web-supplemented instruction. Innovative Higher Education, 3(1), 67-82.

Wood, R.E., Bandura, A., \& Bailey, T. (1990). Mechanisms governing organizational performance in complex decision-making environments. Organizational Behavior and Human Decision Process, 46, 181-201.

Xu, X., \& Yu, K. (2019). When core self-evaluation leads to career adaptability: Effects of ethical leadership and implications for citizenship behavior. Journal of Psychology, 153(5), 463-477.

Yoon, M.H., \& Yoon, D.J. (2019). When and why does relative leader-member exchange enhance service performance?: The roles of self-efficacy, team commitment, and multi-foci team-level differentiation. International Journal of Contemporary Hospitality Management, 31(7), 26662690.

Zajacova, A., Lynch, S.M., \& Espenshade, T.J. (2005). Self-efficacy stress, and academic success in college. Research in Higher Education, 46(6), 677-706. 